\title{
CRIMINAL ATTEMIPTS-THE RISE AND FALL OF AN ABSTRACTION
}

\section{THURILAN TI. ARNOLDO}

A DISCUSSION of the law of criminal attempts usually commences with the statement that the problems involved are intricate and difficult to solve and that the cases are hopelessly confused. Legal problems are spoken of as confused under two different sets of circumstances. First, where courts are doing inconsistent things with similar fact situations, and second, where courts are attempting to make the same rule cover utterly dissimilar situations. In the first case the legal writer usually attempts to justify one treatment or the other. In the second case he makes an effort to reformulate the rules so that all or a great majority of the cases may appear reconciled with them. This often involves the making of generalizations even broader and vaguer than the original ones. It also usually involves the creation of elaborate logical machinery for sorting the dissimilar situations without exposing their complete dissimilarity. Once this is done the opportunity is given to ingenious attorneys to search far and wide for cases which no one would ever consider treating the same as the case being argued except for the fact that they come under the same so-called genexal principles and the court speaks of them all in the same general language. These cases must be distinguished, and of course the court has great difficulty in doing so. In the attempt, however, hundreds of pages of legal literature are written. The result is a statement like this:

"It has been truly said by a philosophical writer that 'the subject of criminal attempt, though it presses itself upon the attention wherever we walk through the fields of criminal law, is very obscure in the books, and apparently not well understood either by the text-writers or the judges.' And it may be added that it is more intricate and difficult of comprehension than any other branch of the criminal law." 1

This despairing remark was made in a case where the defendant was charged with attempting to poison with intent to kill by buying poison, delivering it to a third party, and asking her to put it in the coffee of the intended victim. The court was driven to this language after comparing the case with one of an indict-

\footnotetext{
* Dean of West Virginia University Law School; Visiting Professor, Yale University Law School (1930-1931).

I Hicks v. Commonwealth, 86 Va. 223, 226, 9 S. E. 1024,1025 (1889).
} 
ment for attempting to contract an incestuous marriage where the defendant had eloped with his niece and sent for a magistrate to perform the ceremony. ${ }^{2}$

Another statement reads as follows:

"The doctrine of attempt to commit a substantive crime is . one of the most important and at the same time most intricate titles of the criminal law. There is no title, indeed, less understood by the colurts, or more obscure in the text-books than that of attempts." 3

This occurs in a case where the defendant was indicted for attempting to obstruct and impede the administration of justice by giving $A$ money, unlawfully to induce a witness to absent himself from court. The court sought light on the problem by considering (1) indictments for the possession of forged bank bills, (2) a case involving the form of an indictment for an attempt at larceny, (3) the evidence in a case where the defendant offered money to another person to set fire to a barn and furnished him matches, and (4) cases where a request to commit adultery was held not to be indictable. In nearly all opinions on attempts the same process is repeated. ${ }^{4}$ The courts,

\footnotetext{
2 People v. Murray, 14 Cal. 159 (1859). See infra note 4.

${ }^{3}$ Cunningham v. State, 44 Miss. 685, 701 (1874). Similar statements aro frequent. E.g., "It is impossible to decide any case on this subject without doing violence to some author or some adjudicated casc." Stokes v. Stato, 92 Miss. 415, 425, 46 So. 627, 628 (1908). See also 1 Bishop, Criminal LAw (9th ed. 1923) § 725; 8 R. C. L. 276; State v. Bowles, 70 Kan. 821, 79 Pac. 726 (1905) ; State v. Bütler, 8 Wash. 194, 35 Pac. 1093 (1894).

4 This is perfectly illustrated by following the strange career of People v. Murray, 14 Cal. 159 (1859), supra note 2. A conviction for an attempt at an incestuous marriage was reversed on the theory that the defendant had not gone beyond acts of preparation. In as much as he had done practically everything possible, except actually perform the ceremony, the case is most useful for all who desire to prove that any series of acts of whatever nature have not gone far enough to constitute an attompt. It has been cited with amazing frequency throughout the attempt cases, the following being a few examples:

State v. Davis, 319 Mo. 1222, 6 S. W. (2d) 609 (1928), where the defondant paid money to a party to kill someone for him; the incestuous marringo case, among others, comforted the court in its conclusion that hiring someone to kill someone else was not an overt act on the part of defendant "moving directly toward the commission of the offense." State v. Addor, 183 N. C. 687,110 S. E. 650 (1922), an indictment for unlawful attempt to manufacture intoxicating liquors where defendants had collected bariels and other paraphernalia; the incestuous marriage case, among others, all equally irrelevant, led the court to express itself as follows: "The alleged attempt did not amount to a direct, ineffectual act towards the present manufacture of spiritious liquors, to a 'commencement of the consummation', but, as indicated in the opinion of Chief Justice Fields in the California case [the incestuous marriage case], the said acts consisted only in 'devising or arranging the means or measures necessary for the commission of the offense." A dissenting opinion indicates some alarm over
} 
while admitting they get no assistance from these far fetched analogies, seem unable to avoid using and trying to distinguish them, because they all appear to be part of the law of "criminal attempts."

What both courts and textwriters allege they are seeking are the earmarks by which one can recognize an attempt regardless of what is being attempted. We have a sufficiently clear picture in our mind of what conduct constitutes arson, rape, murder and robbery. Of course it is blurred at the edges but we do not talk about these crimes as hopelessly confused. Why can we not be equally successful with the crime of attempt? Let us take a few cases where the question might arise:

(a) A man attempts to drive his automobile through the street at sixty miles an hour. Suppose the automobile will only

future prohibition enforcement as a result of this decision. Cornwell $v$. Fraternal Accident Ass'n, 6 N. D. 201, 69 N. W. 191 (1896), a suit on an accident insurance policy where it was held that hunting prairie chickens with a loaded gun is not attempting to kill them. State v. Dumas, 118 Minn. 77, 136 N. W. 311 (1912), in which the court had difficulty in distinguishing attempted arson with attempt at incestuous marriage. State v. Wood, 19 S. D. 260, 103 N. W. 25 (1903), in which the language of the incestuous marriage case saved the defendant from conviction for an assault with a sharp and dangerous weapon.

Likewise People v. Di Donato, 90 Cal. App. 366, 265 Pac. 878 (1928) (murder in connection with attempted burglary); Ex parte Floyd, $7 \mathrm{Cal}$. App. 588, 95 Pac. 175 (1908) (conviction for attempt to forge reversed because act mere solicitation); People v. George, 74 Cal. App. 440, 241 Pac. 97 (1925) (conspiracy to obtain money by false pretenses); People v. Gilbert, 86 Cal. App. 8, 260 Pac. 558 (1927) (attempt to commit burglary); People v. Parker, 74 Gal. App. 540, 241 Pac. 401 (1925) (lewd act); People v. Petros, 25 Cal. App. 236, 143 Pac. 246 (1914) (pandering); Patrick v. People, 132 IIl. 529, 24 N. E. 619 (1890) (attempt to rescue prisoner); State v. Thompson, 118 Kan. 256, 234 Pac. 980 (1925) (attempt to assist in an escape from jail); Commonwealth v. Peaslee, 177 IIass. 267, 59 N. E. 55 (1901) (attempt to burn building); People v. Youngs, 122 Mrich. 292, 81 N. W. 114 (1900) (conviction for attempt to enter building reversed on authority of incestuous marriage case) ; State v. Rains, 53 IIont. 424, 164 Pac. 540 (1917) (attempt at murder); Territory v. Reuss, 5 Mront. 605, 5 Pac. 885 (1885) (attempt to kill by placing bomb on intended victim's porch; dissenting judges use incestuous marriage caso to show this was an act of preparation); Johnson v. State, 27 Neb. 687, 43 N. W. 425 (1889) (assault with intent to rape); State v. Lung, 21 Nev. 209, 28 Pac. 235 (1891) (attempt at rape by mixing cantharides in coffee); Cole v. State, 14 Okla. Cr. Rep. 18, 166 Pac. 1115 (1917) (solicitation to commit adultery not an indictable attempt because, among other reasons, it was "merely preparatory"); Ex parte Turner, 3 Okla. Cr. Rep. 168, 10.4 Pac. 1071 (1909) (attempt at murder); Bryant v. State, 7 Wyo. 311, 50 Pac. 596 (1899) (assault with intent to kill compared with attempt to commit incestuous marriage); Hicks $\nabla$. Commonwealth, supra note 1; People v. Rizzo, 246 N. Y. 334,158 N. E. 888 (1927), infra note 61.

This list contains by no means all the cases in which this incestuous marriage case has been cited. We stop only because we feel our point has been sufficiently illustrated. 
go fifteen miles an hour, or is out of gas, or is in running condition and the driver is just climbing in."

(b) Four boys intend to take an automobile for a joy-ride and are arrested as they take their seats. A special statute punishes the conduct they have attempted."

(c) The law makes the manufacture of liquor a felony. The defendant sets up a still and is preparing some mash when he is arrested.?

(d) A man attempts to kill another. He fails because the gun is not properly loaded. ${ }^{8}$

(e) A boy under fourteen attempts to commit rape.

${ }^{5}$ Attempts at speeding are not prosecuted. If such a prosecution woro commenced would it not be sensible to discharge the defendant on the ground that the policy of the particular statute did not include attempts? Or should we adopt the device used in People v. Murray, supra noto 2, and say that any act outside actual speeding was "mere preparation"?

- Held to be an attempt though the crime attempted was malum prohibitum. People v. Bauer, 216 Mich. 659, 185 N. W. 694 (1921).

7 The result here will depend upon our attitude toward the prohibition law. Obviously the word "manufacture" can be applied to all steps in tho process from the beginning to the end. Yet courts seem to feel that until whiskey is actually produced no manufacturing has been done. Stato v. Addor, 183 N. C. 687,110 S. E. 650 (1922), 22 A. L. R. 219 (1923) (defendant not guilty); Mote v. State, 205 Ala. 80, 87 So. 628 (1920) (defendant guilty where fire yet running under still). See also Powell v. State, 128 Miss. 107, 90 So. 625 (1922); Shoemake v. State, 17 Ala. App. 461, 86 So. 151 (1920); White v. State, 27 Ga. App. 769, 109 S. E. 917 (1921).

8 This covers a variety of offenses, most of them found under the heading of assaults, such as assault with intent to kill, assault with intent to inflict bodily injury, assault with a dangerous weapon, presenting a londed firearm, shooting, etc. It also may be an attempt. See infra note 33.

- Various solutions are offered by various courts and writers:

(a) The boy is guilty of an attempt, although he is presumed to bo incapable of rape, as one can always attempt the impossible. Benle, Criminal Attempts (1903) 16 HARv. L. REv. 491, 498, citing Davidson v. Commonwealth, $20 \mathrm{Ky}$. L. Rep. 540, 47 S. W. 213 (1898); Commonwealth v. Green, 2 Pick. 380 (Mass. 1824). Mr. Beale admits, howevor, that tho weight of authority is against this theory.

(b) The boy is not guilty in a jurisdiction where ho is presumed to bo impotent because he cannot attempt to commit an offense which ho is physically incapable of perpetrating. See cases cited by Beale, op. oit. supra at 498, n. 5; Sayre, Criminal Attempts (1928) 41 HARv. L. Rev. 821, 840, n. 70; Strahorn, Effect of Impossibility in Criminal Attempts (1028) 78 U. of PA. L. Rev. 962, 986, n. 57. Cases are collected in Note (1897) 36 L. R. A. 204; 33 Cyc. 1430, n. 25.

(c) The boy is not guilty because "the factual objective in the boy's mind, that is, carnally to know the girl, does not in fact constitute the crime of rape; and it is quite immaterial whether the boy believes that what he is committing is rape or not." Sayre, op. cit. supra at 840 .

(d) The boy is not guilty because "if there be juridical incspacity for tho consummated offense (e.g., infancy), there can be no conviction of the attempt." 1 WharTON CRIMINAL LAW (11th ed. 1912) § 223.

(e) The boy is not guilty because legal impossibility excuses "when it 
(f) An intoxicated negro drives down the street at a reckless rate of speed, causing injury to someone. He is indicted under a special statute for assault with intent to murder: $0^{10}$

Let us ask ourselves the question whether there is any similarity in the various kinds of conduct for which the various defendants above are indicted. Are the reasons why the defendant should be free or convicted in any of these cases at all similar? Is there any similarity in the more immediate purposes of the legislature in creating the above crimes? Obviously there is not. These crimes are aimed at different kinds of conduct and to protect society against entirely different things. Why by classing them together should we compel courts to distinguish the speeding case where the defendant is discharged and the assault with intent to kill case where he is convicted?

Originally the word "trunk" was applied to trees. Suppose later a writer on the science of things in general classifies "elephants," "trees" and "tourists" under the same heading. The reason for such a classification is that all three possess trunks. The answer to the objection that the trunks are of different kinds can easily be met by saying that to a nicely balanced analytical mind, they all have one inherent similarity, i.e., they all are used to carry things. The elephant's trunk carries hay to the elephant's mouth, the tree trunk carries sap to the leaves and the tourist trunk carries clothing. The soundness of the new abstraction cannot perhaps be disputed but nevertheless

has the effect of negativing the existence of any interest to be protected by the major prohibition against the consequence desired by the defendant." In other words, "Of course, a boy under fourteen who attempts rape would be guilty of common assault, and to that extent to which the law does protect the interests of females against boys, she will be protected and he will be punished. The interest to be free from bodily harm or the fear thereof must be distinguished from the interest to be free from the forcible capture of sexual favors and the fear thereof." Strahorn, op. cit. supra at 987.

${ }^{10}$ In Chambliss v. State, 37 Ga. App. 124, 139 S. E. 80 (1927), the defendant was held guilty of assault with intent to murder. The automobile cases furmish a very interesting illustration of how courts have used the penalties provided in assault statutes, traditionally treated as attempts, to punish reckless driving where the reckless driving penalties have been found inadequate. This process has gone so far that writers on attempt are compelled to ignore these cases, although much of the support for their machinery comes from cases of aggravated assault. Decisions and statutes of this kind are discussed in an able article by Leon A. Tulin, The Role of Penalties in Criminal Law (1928) 37 Tare L. J. 1048. See also annotations, (1922) 16 A. I. R. 917; (1922) 21 A. L. R. 1504; (1923) 27 A. L. R. 1182; (1924) 30 A. I. R. 66; (1926) 41 A. L.R. 725; (1926) 42 A.L.R. 1120; (1927) 46 A. L. R. 1060; (1927) 49 A. L. R. 608; (1928) 53 A. L. R. 254. It is interesting to note that these annotations treat assault with an automobile as the same kind of a thing and as an incident to manslaughter with an automobile (which is exactly what it is), instead of trying to segregate it and treat it as a part of the law of attempts. 
the classification would create at least verbal confusion and the necessity for a great many fine distinctions. ${ }^{11}$

On the other hand it is obvious that if we malke attempt at murder a substantive crime we have narrowed our generalizations sufficiently so that the cases are much less difficult to handle than if we make attempts in general a substantive crime. How far a man may go in his preparations to kill another man would, of course, never be exactly determinable in advance, but at least we have concentrated our field of observation as much as we can. We would not need to clutter up our briefs or our opinions with citations of cases where the defendant was trying to commit arson or bigamy or some misdemeanor. We could discard most of the present elaborate logical machinery as useless and misleading.

\section{HISTORY, OF CRIMINAL ATTEMPTS}

The reason why we must try to talk about criminal attempts without relation to the particular crime attempted is found in the attitude of the legal mind of the Eighteenth Century. Mr. Thomas Reed Powell describes that attitude as follows:

"If you think you can think about something which is attached to something else without thinking about what it is attached to, then you have what is called a legal mind." 12

The earliest cases on attempt do not try to describe "attempts" in general; they justify conviction for an attempted crime by the formula, voluntas reputabitur pro facto.

"Since there existed no general doctrine that attempts as such were punishable, in the more extreme cases, such as killing and robbery, results much desired could be had by borrowing from the ecclesiastical courts a doctrine which conveniently allowed the will to be taken for the deed." ${ }^{23}$

11 The uselessness of present abstractions in the law of attempts may bo seen from the following example: "Commission means the act of committing, doing or performing; the act of perpetrating." "The attempt is the direct movement toward the commission after the preparations aro made." From these statements it becomes clear that a defendant who has built a still and is working on top of it when arrested is engaged in more preparation and is not guilty of an attempt to manufacture, citing tho incestuous marriage case. Coffee v. State, 39 Ga. App. 664, 148 S. E. 303 (1929). See also Lee v. Commonwealth, 144 Va. 594, 599, 131 S. E. 212, 214 (1926), to the effect that an attempt is "the commencement of the consummation."

12 From an unpublished manuscript.

${ }^{13}$ Sayre, op. cit. supra note 9 , at 827 . For the historical development of the law of criminal attempt the writer is indebted chiefly to Mr. Sayro. It is restated here, however, from a different point of view. 
Of course this generalization did not mean that courts would punish for mere intent. This has been shown in Mr. Sayre's very careful historical analysis of the doctrine of attempts. The phrase was simply a shorthand expression for the idea that in the case of certain criminal conduct which might easily have resulted in a crime the failure to achieve that result did not necessarily indicate that the criminal would not be punished. In short, no substantive law of criminal attempts and no definition of the abstraction "attempt" was required. As MIr. Sayre says in discussing an early case of attempted subornation of perjury:

"The interesting fact is that the court in convicting the defendant made no mention of any convenient general doctrine that the attempt to commit any crime is as such criminal; but instead apparently followed the line of thought that any effort to subvert justice by corrupting a witness is of itself a complete substantive offense." 14

This rule is no more than an assertion of the power in a court to extend the policy of a given rule prohibiting a crime to certain acts which had failed to achieve the prohibited result. The advantage of this way of talking about a case lies in the fact that it appears to classify the criminality of the attempt under the heading of the crime attempted. Such treatment, had it continued, would have eliminated the necessity of trying to define attempts without reference to what is attempted. An examination of the rule prohibiting the substantive crime would have been our only guide in determining how far conduct which failed of that result should be punished.

The Eighteenth Century method of legal analysis, however, refused to admit frankly that courts by the exercise of a certain limited discretionary power could extend the limits of substantive crimes. To satisfy that habit of mind it became necessary to classify all attenipts as a species of substantive crime in themselves. In other words, the man who attempted arson, the man who attempted murder, and the man who attempted a misdemeanor were in theory all guilty of the same substantive offense. In the words of Lord Mansfield:

"There was a distinction made at the bar between an act done with intent to commit a felony and an act done with intent to commit a misdemeanor. In the degrees of guilt there is a great difference in the eye of the law but not in the description of the offense." ${ }^{15}$

In short, it is decreed by Lord Mansfield that there is such an offense as attempt existing independently of the thing attempted.

14 Sayre, op. cit. supra note 9 , at 830.

15 Rex v. Scofield, Cald. 397, 402 (1784). 
Criminals may be classified into murderers, thieves, etc., and attemptors.

Once recognized as a separate crime, an attempt must necessarily be capable of division into constituent elements. Failure to find them would simply mean that we had not clone sufficient analytical thinking. Thus commences our search for abstractions which will classify all sorts of dissimilar situations together, and which will enable us to apply the same rules to cases requiring different kinds of treatment.

Sometimes the rule which the courts are considering is the old common law jurisdiction over attempts. Generally, however, they are using the doctrines of attempt to interpret statutes covering many kinds of conduct and providing many different penalties. Any discussion of the law of criminal attempts therefore requires consideration of its usefulness in the interpretation of such statutes.

\section{STATUTES COVERING CRIMINAL ATTEMPTS}

While the common law writers have been busily engaged in trying to make all attempts look alike the legislatures have been equally busy putting attempts back where they belong as adjuncts of the particular crime attempted. Yet, in the interpretation of these statutes, the general rules regarding attempt are still used, and it is out of such cases that the formulne of criminal attempt are drawn.

The statutes may be roughly divided into four different kinds: (1) Statutes using the terminology of assault. Such statutes include assaults with intent to murder, ${ }^{26}$ kill, maim, rape, rob, steal, poison; assault with intent to commit any felony; assault with intent to commit various sexual offenses where violence is not essential; assaults in the first and second degrees.

(2) Statutes using the terminology of attempt, and applying it to particular crimes. ${ }^{17}$ Such statutes include attempts at murder, arson, abortion, bribery, escape, burglary, robbery, prostitution, dueling, forgery, indecent offenses, vote buying, influencing jurors, suborning perjury, attempting to practice dentistry, attempting to entice away employees, and many others.

16 Sometimes attempt at murder and assault with intent to murder aro made different crimes. Massachusetts, for instance, punishes assault with intent to murder with a maximum of ten years, MASS. GEN. LAWs (1921) c. $265, \S 15$, and attempt at murder by any means not constituting an assault with a maximum of 20 years, $i b i d$. $\S 16$. The distinction is one frequently made, leading to much confusion. Infra notes 31,32 and 33 .

17 Often the language is similar to the following: "Any person who shall procure or attempt to procure or be concerned in procuring . . . a femalo inmate of a house of prostitution ...." Tex. CR. STAT. (Vernon, 1928) Art. 519. "Whoever shall invite, solicit, procure, allure or use any menns in alluring or procuring any female...." Ibid. Art. 525. 
It is difficult to find any kind of attempt of frequent occurrence which is not included in some special attempt statute.

(3) Statutes which omit to use either the words "assault" or "attempt," but which prohibit practically the same kind of conduct as falls within the attempt and assault statutes. These include such crimes as abusing girls under age with indecent intent, presenting firearms, shooting or stabbing with intent to kill, taking indecent liberties, offering to bribe. ${ }^{28}$

(4) Statutes giving the court power to punish for attempts generally without linking up these attempts with any particular. crime mentioned in the statute. Such statutes are generally spoken of as declaratory of the common law. They usually, however, provide a very different scale of penalties..$^{10}$

The impossibility of building any general logical scheme around these statutes results not only from the fact that they cover such obviously unrelated fields of human conduct, but also because they are not at all consistent in their penalties. ${ }^{-0}$ The

18 A frequent device is to provide a different penalty for "unlarful" and "malicious" action. Thus, in Virginia, shooting, stabbing or wounding with intent to maim, disfigure, disable or kill is punishable by a maximum of ten years. If, however, it is done "unlawfully but not maliciously" with the intent aforesaid, the maximum is a jail sentence of not more than ten months. Shooting at another person in a place of public resort or on a street is an entirely different offense with a slightly different penalty. Shooting in committing "or attempting to commit a felony" is a third separate offense. VA. GEN. LAws (1923) $\$ \S 4402-4404$.

13 The following are typical examples of general attempt statutes: "Whoever attempts to commit a crime by doing any act toward its commission, but fails in its perpetration, or is intercepted or prevented in its perpetration, shall, except as otherwise provided, be punished as follows. ..." MLass. Gen. Latws (1921) c. 274, § 6. Cf. CoNN. Gen. Stat. (1918) \$ 6374; MícH. CoMrP. Laws (Cahill, 1915) c. 263; MIo. Rev. Star. (1919) $\S 4894$; N. J. Conip. STAT. §§ 216-218; N. Y. CoNS. LATS c. 41, § 261; N. D. CoMr. LaWs (1913) § 10338; OkLA. Rev. LaWs (1921) § 2297; VA. CODE ANN. (1919) § 4767; MatNe Rev. Stat. (1916) c. 133, § 10; W. VA. CODE ANN. (Barnes, 1923) c. 152, $\$ 9$.

20 Often there is more than one statute covering the same conduct but prescribing different penalties. For example, in Indiana: "Buying votesPenalty. ... Whoever attempts to induce any person to vote or refrain from voting for any candidate... by offering such person any reward or favor shall be fined ... not more than fifty dollars and disfranchised for ... a period of ten years. ..." IND. ANN. Stat. (Burns, 1926) $\S 2913$. On the other hand if a person is solicited to vote in another precinct the fine is $\$ 50$ to $\$ 1000$ and the imprisonment, vhich is compulsory on the court, is one to five years. Ibid. $\S \S 2920,2921$.

Almost any prohibition law offers a whole seale of penalties for conduct which is substantially the same. When the generalizations of attempt are superimposed on attempt to violate prohibition laws the language becomes almost unintelligible. Take Iowa as an example. Selling, keeping or manufacturing liquor is one offense, IOWA CODE ANN. (1925) § 1924, while 
widely varying penalties naturally lead to widely varying interpretations of the statutes. When a crime carrying a $\$ 500$ penalty is classified with one carrying five years in the penitentiary and the same rules applied to each the language gets further and further from reality. ${ }^{21}$

One way of treating cases arising under these statutes is to determine whether the policy of the statute can be said to include the conduct of the defendant and whether the penalty seems appropriate to the offense. If we do this we can confine our attention to the particular prohibition under discussion, and decide to what conduct we wish to extend it. Another method is to forget the particular statute which the defendant is alleged to have violated or the particular crime which he has almost consummated, and put our emphasis on words in the statute such as "assault" and "attempt." When we do this every other statute, no matter how different in policy or penalty, and attempts at every other crime no matter how dissimilar immediately become relevant. We are thereupon forced to create numerous fine distinctions and abstract concepts such as the following:

(1) A classification of crimes into those which are in the nnture of attempts, and hence cannot be attempted, and those which can be attempted.

(2) A distinction between an assault and an attempt.

(3) A distinction between a solicitation and an attempt.

(4) A general formula of intent which can be applied to anything.

(5) General definitions of "preparation" in the abstract, the inherent meaning of the words "present ability;" distinctions between acts done under a mistake of fact and acts done with inadequate instruments, and many others.

Are such general conceptions useful legal tools or do they create confusion and technicalities? This can best be answered by considering the logic of criminal attempt in more detail.

keeping with intent to sell in a building, ibid. $\$ 1929$, keeping liquor or assisting in keeping it in a club room, ibid. $\S 1933$, drinking on trains, $i$ ibid. $\S 1937$, are all different offenses with different penalties. So also illegal transportation, ibid. $\$ 1945 \mathrm{a}$, carrying liquor on trains, ibid. $\$ 1937$, concealing the fact that a package carried contains liquor, ibid. $\$ 1934$, and unlawful delivery by carriers, or any other person, ibid. $\S 1043$, are distinct offenses with varying penalties.

There is an equally great variety of statutes punishing different kinds of indecent conduct. For example, see TEx. CR. STAT. (Vernon, 1928) Tit. 10: "Offenses against Morals, Decency and Chastity," which includes about forty different offenses. There are hundreds of different kinds of assaults and special attempts at different crimes of violence.

${ }^{21}$ See Tulin, op. cit. supra note 10. 


\section{ATTEMPTED RATIONALIZATION OF ATTEMIPTS}

In order to make this examination we must attempt to summarize, which is not easy because writers are not in accord as to the proper form the generalizations should take.

"It was not until almost the end of the 18th Century, however, that under the creative genius of Lord Mansfield a generalization was formulated covering attempts to commit crime as such; the present doctrine therefore is essentially a modern one, and it is not unnatural that its limits are still somewhat uncertain." 22

The first problem, however, seems to be the creation of a rule determining what crimes may be attempted. The usual statement is: Any attempt to commit any crime is a substantive offense amounting to a common law misdemeanor..$^{23}$

This represents Lord Mansfield's view and in varied forms has been copied in the general attempt statutes. It is obviously not true-attempts at many crimes are not punishable at all. Therefore we must try to make distinctions. One of the most frequent is this: If the offense be a misdemeanor which is "malum prohibitum," "purely statutory," or "not malicious," its attempted commission will not be criminal.".

Such words always make trouble. The phrase "malum prohibitum" has lost its historical meaning. ${ }^{.5}$ Used here we cannot

22 Sayre, op. cit. supra note 9 , at 837.

23 "An attempt to commit any crime; treason, felony, or misdemeanor, is itself criminal, though the attempt fails." Beale, op. cit. supra note $\mathbf{9}$, at 491 . See also WHARTON, op. cit. supra note 9, at § 212; BISHOP, op. cit. supra note 3 , at $\$ 772$.

24 This language is taken from 16 C. J. 111. For the argument that attempts at offenses not mala in se are not indictable, see Wharton, Criminal Attempts (1883) 17 CENT. L. J. 26. Compare the following statements: "It is urged that though made a felony by the statute the offense is ono malum prohibitum and not malum in se and that as to the former an attempt to commit it is not indictable.... This rule can have no application in this state. Under our statute an attempt is punishable even if the punishment for the offense be a fine or imprisonment in the county jail." People $\nabla$. Bauer, 216 Mich. 659, 185 N. W. 694 (1921). "It is elementary law that an attempt to commit a misdemeanor is not an indictable offense." State v. Redman, 121 S. C. 139,113 S. E. 467 (1922). "An attempt to commit a misdemeanor is a misdemeanor." Mrote v. State, 17 Ala. App. 526,87 So. 628 (1920).

${ }^{25}$ Blackstone considered crimes mala in se to be crimes against the law of nature and crimes mala proinibita those owing their origin not to the law of nature but to civil society. 4 Blackstone, Cosratentaries 8 . Hence statutory crimes not originating at common law were mala prohibita. But the notion that the common law is more sacred than statute law is dying. Hence we swing back to the idea that crimes mala in se are those that are "intrinsically wrong." See State v. Trent, 122 Ore. 444, 252 Pac. 975 (1927) ; 13 R. C. L. 848; BISHop, op. cit. supra note 3 , at $\S 323$. But what 
even take it to mean that serious crimes may be attempted and less serious ones may not. Certainly driving while intoxicated is a more serious crime than an attempt at smuggling lace, yet it is not one which will be extended so as to punish attempts. The rule therefore amounts to no more than that some attempts are punishable and others are not.

A second qualification may be stated as follows: There can be no attempt to commit a crime which is in itself an attempt.20

This may sound logical but it assumes that we are able to tell whether a crime is in its nature an attempt.27 Are the offenses of driving while intoxicated, violation of the Mann Act, indecent solicitation, shooting dangerous firearms, assault with intent to kill, to rape, to maim, crimes which are attempts at something else? And if so, what bearing should this have upon our method of dealing with them?

The distinction is sometimes made between acts which are criminal because of their consequences, and those which are criminal because of the surrounding circumstances-an act being defined as a willed muscular contraction. ${ }^{28}$ But how can one separate the consequences from the surrounding circumstances? And if that is possible, how does one know whether it is the consequences or the surrounding circumstances which makes the act criminal? The defendant marries when his first wife is alive. Is it the consequences or the surrounding circumstances of the second marriage which makes the willed muscular contraction involved in the second ceremony criminal? Is it the consequent noise involved in the willed muscular contraction of the throat or the surrounding circumstances which makes blasphemy criminal?

is "intrinsically wrong"? See Note (1929) 43 HARv. L. REv. 117, discussing "moral turpitude;" Greenfield, Malum Prohibitum (1921) 7 A. B. A. J. 493.

26 The language is taken from 16 C. J. 111. See also Wilson v. State, 53 Ga. 205 (1874), where a conviction was reversed because the jury found a verdict for attempt to assault whereas the law knew no such crime.

${ }^{27}$ Bishop tries to do it this way: There are two classes of cases-thoso in which the criminality comes primarily from the act, and those in which it proceeds either primarily or in part from the specific intent as distinguished from general malevolence of mind. The doctrine of attempt applies only to the latter class. For in the former class, where the guilt is measured primarily by the act and only general malevolence is required to be shown, if the act has proceeded far enough for the law to notice it, it constitutes a substantive offence and is not an attempt. BISHOP, op. cit. sutpra noto 3, at § 729 .

Wharton is simpler: "But to make an attempt indictable it must bo to commit a consumated, not an inchoate offence. Hence no indictment lies for an attempt to commit an attempt or assault." WHARTON, op cit. supra note 9 , at $\S 212$.

${ }_{28} \mathrm{Mr}$. Sayre refers to this distinction although it is not clear whether ho intends it to have any bearing upon the problem of what crimes may bo attempted. Sayre, op. cit. supra note 9, at 838, n. 64, 65. 
One author divides the field into direct and relative attempts.=0 In the former recourse to the principles of the major crime is unnecessary, whereas in the latter this process appears to be necessary. There can be no attempt at a direct attempt. But the query immediately arises, Why not? We do not punish attempts at ordinary assaults which carry light penalties. But suppose the accused is guilty of conduct tending toward an aggravated assault but which does not seem to require the heavier penalty. The court is confronted with the alternative of either discharging the accused or modifying the penalty to make it more nearly fit his conduct. An easy way to accomplish this is by making attempts at aggravated assaults punishable, and this is frequently done..$^{30}$ It is academic to call such cases "wrong" because assault is in the nature of an attempt and hence cannot be attempted, particularly when a common sense result is reached. In short the generalization that there can be no attempt at a crime in the nature of an attempt tells us nothing and tends merely to divert the cour't's mind from the real issue.

The distinction between attempts at ordinary crimes and attempts at crimes in the nature of an attempt necessitates another difficult concept which we may state as follows: There is a fundamental distinction between an assault and an attempt. ${ }^{31}$

An assault is usually defined as an unlawful attempt coupled with the "present ability" to commit a violent injury. An assault therefore seems to be an attempt plus something else. Consequently when an accused is indicted for an assault his attorney will endeavor to show the court that the crime committed was actually a mere attempt. If the court is to reach a non-technical result and yet hold the accused its reasoning must become very technical indeed. For example, in a California case, $^{32}$ the defendant put a tin box of gun powder in a stove and was in another county when the explosion occurred. He was found guilty of assault with a deadly weapon. Did he have

29 Strahorn, op. cit. supra note 9, at 963 .

30 For example a negro was indicted for assault with intent to commit rape, the minimum penalty being two years. The evidence showed that he merely frightened a woman by accosting her. He was sentenced to six months imprisonment on conviction for "an attempt to commit an assault with intent to commit rape," which sentence was affirmed. Burton $\nabla$. State, 8 Ala. App. 295, 62 So. 394 (1913). In State v. Herron, 12 Mront. 230, 29 Pac. 819 (1892), the indictment was drawn for attempt to commit an assault with a deadly weapon, probably because the state could not prove the gun was loaded and therefore wanted to avoid the technicalities of the phrase "present ability." A conviction was sustained.

31 Ross v. State, 16 Wyo. 285, 93 Pac. 299 (1908); People v. Lee Kong, 95 Cal. 666, 30 Pac. 800 (1892) ; People v. Gardner, 98 Cal. 127, 32 Pac. 880 (1893) ; Miller v. State, 84 Tex. Cr. App. 168, 206 S. W. 524 (1918).

32 People v. Pape, 66 Cal. 366, 5 Pac. 621 (1885). 
"present ability" to inflict injury when he put the box in the stove? In order not to discharge him the appellate court was forced to assert that he had. Yet at the same time it reaffirmed the fundamental distinction between an assault and an attempt. Had the court been free to dispense with this generalization its opinion would have been shorter and more intelligible. The results of the use of the concept "present ability," moreover, are not always so fortunate. ${ }^{33}$

Since "attempt" is a definite substantive crime it follows that it must be distinguished, from "solicitation;" hence the invention of a new abstraction, "solicitation" without reference to the thing solicited. The rule may be stated as follows: Solicitation is a separate offense from attempt though both are common law misdemeanors. ${ }^{34}$

"Analytically the two crimes are distinct. Each has its own peculiar features; clearly not every indictable solicitation can be considered an indictable attempt. . . In spite of their many similarities, therefore, these two crimes should not be confused." 35

Courts talk about solicitation in two classes of cases. (a) Where a defendant has been indicted for attempt and his acts are not sufficiently serious to come within the policy of the criminal prohibition invoked he is often held not guilty of an

${ }^{33}$ Where $A$ points a gun at $B$ and there is no proof that it is loaded, tho following questions arise:

(a) Does a man with an unloaded gun have present ability?

(b) If he thinks it is loaded does he have apparent present ability?

(c) Does the state have to prove the gun is loaded or is there a presumption to that effect?

For collections of conflicting decisions see annotations in (1908) 15 L. R. A. (N. s.) 1272 ; (1913) 41 L. R. A. (N. s.) 181; (1913) 42 L. R. A. (N. S.) $975 ; 5$ C. J. 725.

(d) If $A$ is lying in ambush to kill $B$ who never knows that an assault is contemplated, is this an assault? No. State v. Barry, 45 Mont. 598, 124 Pac. 774 (1912). Yes. People v. Lilley, 43 Mich. 521, 5 N. W. 982 (1880). Cf. People v. Pape, supra note 32.

(e) If instead of a gun, poison is put where $B$ may get it, is this an assault, or is it an attempt? If it is not an assault how can we distinguish it from case (d) above?

(f) If the case is one under a statute of assault with intent to kill aro wo going to preserve the same definition of assault that we did under the simplo assault cases? Cf. People v. Pape, supra note 32.

34 "It seems to be clear that the common-law misdemeanor of attempting to commit an offense cannot be accomplished by the solicitation of another to do the act." Beale, op. cit. supra note 9, at 505. See also WharroN, op. cit. supra note 9 , at $\$ 218$. For guarded statements that the weight of authority seems to hold that solicitation cannot be an attempt see: $8 \mathrm{R}$. C. L. § 295; 16 C. J. § 98; and Notes in (1889) 3 L. R. A. 747; (1894) 25 L. R. A. 434 ; L. R. A. 1918 A 98.

35 Sayre, op. cit. supra note 9 , at 857. 
attempt because what he did was a mere solicitation. ${ }^{30}$ Actually the problem here is of the same kind as is involved in the definition of mere preparation. The only question before the court should be whether to extend the policy of the statute to cover the conduct of the defendant. ${ }^{3 \pi}$ To try to draw an artificial distinction between solicitation and attempt simply results in rather absurd technicalities. For example, in the recent case of State v. Lowrie, ${ }^{38}$ a wife hired another person to kill her husband. The conviction was reversed because she should have been indicted for solicitation. The case involved the interpretation of a statute but the court forgot the statute in its desire to keep up the distinction between attempt and solicitation.

(b) The second class of cases consists of those where the defendant is indicted for solicitation as a crime in itself. For the solicitation of what crimes will a defendant be indicted? This is a problem very similiar to that involved in the determination of what crimes may be attempted. No generalization can be made without considering the particular crime. ${ }^{53}$ An example of the confusion resulting from the attempt to segregate the crime of solicitation without regard to the thing solicited may be found in the Connecticut case of State $v$. Schleifer ${ }^{40}$ There the defendant made an incendiary speech during a street car strike. The court, under its general power to punish for offenses against the safety of the public, properly held it to be a common law offense. Most of the opinion, however, is taken up with the citation and distinction of cases involving solicitations to commit adultery, to burn buildings, and to commit murder. The court finally came to the conclusion that there is much uncertainty as to what solicitations constitute crimes and what do not. But since "certainty in the knowledge of what is or is not a crime is the safety of the individual,"

36 Becker v. State, 283 Pac. 796 (Okla. 1929); Weaver v. State, 16 Okla. Cr. Rep. 564, 185 Pac. 447 (1919); State v. Riseling, 186 Mro. 521, 85 S. W. 372 (1905); State v. Roby, 194 Iowa 1032, 188 N. W. 709 (1922); Stabler v. Commonwealth, $95 \mathrm{~Pa}$. 318 (1880).

3r Compare solicitation to commit adultery which is neither an attempt (Cole v. State, 14 Okla. Cr. Rep. 18, 166 Pac. 1115 (1917)) nor a criminal solicitation (L. R. A. 1918A 98), with attempted subornation of perjury (48 C. J. Tit. Perjury $\S 196$ ) and attempt to bribe, which can only consist of solicitation but which are punished as attempts.

$3812 \mathrm{~S}$. W. (2d) 43 (MIo. 1928). The pertinent comment of a dissenting judge in this case is as follows: "It is not alone by repeal or holding of constitutional invalidity that an affirmative statute may be rendered inoperative. Judicial construction may be employed to effect the same end, and the doctrines of overt act and accessory before the fact be adopted to assist in the obsequies." A similar case is State v. Davis, $6 \mathrm{~S}$. W. (2d) 609 (Mo. 1928), in which the same judge dissented.

39 The cases are collected in Note (1925) 35 A. L. R. 961.

10 99 Conn. 432, 121 Atl. 805 (1923). 
the court felt obliged to seek that certainty by a ruling that "the solicitation to a crime should be of a crime in every instance where to commit the same offense would be a crime." 41 Such a rule was considered to be "definite and understandable, entirely practical, and completely just." This, of course, leaves one entirely up in the air as to just what solicitation is. It is proper to discourage incendiary speeches if they are sufficiently extreme, but to penalize the publication of all revolutionary books and pamphlets is a step which the courts would not care to take. The problem of dealing with incendiary speeches has nothing whatever to do with the old common law crime of solicitation; it is a problem relating to the orderly handling of strikes and should be discussed with that in mind.

Having marked out as far as possible the limits within which crimes may be attempted, the next step is to discover the elements of an "attempt." There appear to be three requisites.

First, there must be a specific intent to commit the crime.s

This, in turn, gives rise to two queries: (a) what is meant by specific intent, (b) in a case where the defendant was mistaken as to what he was doing what was it that he "intended" to do. Let us take the first of these queries.

(a) Obviously "intent". may mean one thing in one class of crimes and another thing in another. Therefore when we have a crime including all classes of crimes we will never be able to tell satisfactorily what we do mean by "intent." Subjective intent, objective intent, intent inferred from conduct, intent inferred from the presumption that a man intends the reasonable and probable consequences of his acts-all these run into one another, and the last may even be used to include negligence. They are methods of talking fitted to particular cases. From the point of view of a prosecution for attempted murder we say that a man cannot blunder into an attempt; ${ }^{43}$ but the application of this generalization to other situations becomes dangerous, for in some cases reckless conduct may require pun-

41 Compare Wharton's concern over the notion that all solicitations aro criminal: "But to make bare solicitations or allurements indictable as attempts, not only unduly and perilously extends the scope of penal adjudication, but forces on the courts psychological questions which they are incompetent to decide. . . . What human judge can determine that there is such a necessary connection between one man's advice and another man's actions, as to make the former the cause of the latter?" WHARTON, op. cit. supra note 9 , at $\S 218$.

42 WharToN, op. cit. supra note 9, at $\S 215 ; 16$ C. J. 115; Sayre, op. cit. supra note 9 , at 841 .

43 Thacker v. Commonwealth, 134 Va. 767, 114 S. E. 504 (1922), indictment for attempt at murder where the defendant fired three shots into a tent where the witness was sleeping. A conviction was reversed becauso intent could not be inferred. 
ishment fully as much as intended conduct.4s That this is often realized by the courts is evident from such decisions as those holding reckless driving while intoxicated an assault with intent to kill.45 The concept of intent is probably still retained in criminal law because of the desire to have one human element of "blameworthiness" as a basis for punishment. But even so, how can the element of blameworthiness in attempts be acertained without having in mind the thing attempted?

(b) Where the defendant acted under a mistake of fact did he "intend" to do what he mistakenly "thought" he was doing.

(1) Suppose a man shoots at a stump thinking it is his enemy. Did he intend to shoot his enemy, which is criminal, or did he intend to shoot the stump, which is not criminal? ${ }^{45}$

(2) Suppose a boy under fourteen attempts to commit rape? Has he attempted to commit a" crime which is inpossible for him to commit or is the thing which he is trying to do not a crime at all? ${ }^{4 \pi}$

(3) Suppose Lady Eldon tries to smuggle French lace into England when as a matter of fact the lace is not French lace at all but non-dutiable lace, about which she has made a mistake. Shall we say that this is an attempt to smuggle French lace or that what she has attempted to do was to smuggle that particular lace, which was not a crime? ${ }^{48}$

(4) Suppose $A$ attempts to forge a check by raising the figures. Shall we say that he has attempted to commit the crime of forgery in an impossible way or shall we say the thing which he attempted is not a crime? ${ }^{10}$

44 Looney v. State, 153 S. E. 372 (Ga. 1930), assault with intent to murder. Defendants wantonly poured gasoline on a negro and lit a match "to see him run." An instruction stating among other things that on the question of intent to murder the court could consider the brutality of the assault was upheld. In Hankins v. State, 103 Ark. 28, 145 S. W. 524 (1912), an instruction that every sane man is presumed to know the natural and probable consequences of his acts was held proper in a trial for assault with intent to kill. In Jackson v. State, 94 Ala. 85, 10 So. 509 (1892), the court held that "positive and specific" need not be added to words describing intent to kill. See also Scott v. State, 141 Ill. 195, 30 N. E. 329 (1892).

45 Chambliss $\nabla$. State, supra note 10.

46 Wharton says there is guilty intent here but no overt act. WHARTON, op. cit. supra note 9 , at $\S 225$. Mr. Beale thinks there is no guilty intent. Beale, op. cit. supra note 9, at 494 . Mrr. Sayre says there is an overt act and guilty intent but it is not punishable if defendant did not act reasonably. Sayre, op. cit. supra note 9, at 853. Cf. State v. Mitchell, $170 \mathrm{MIo.}$ 633, 71 S. W. 175 (1902); People v. Lee Kong, 95 Cal. 666, 30 Pac. 800 (1892).

${ }^{47}$ See supra note 9.

48 The case is set out in WHARTON, op. cit. supra note 9 , at $\$ 225$.

40 Wilson v. State, 85 Miss. 687,38 So. 46 (1905), held not to be an attempt. 
(5) Suppose the defendant attempts to commit an abortion where the victim is not pregnant. Shall we say that he intended to commit an abortion or that the thing which he is trying to do is not a crime?

It is impossible to apply the same abstract logical system to all of these questions without first disregarding the purposes of the statute. After doing so, there is nothing inherent in any of the situations above outlined which makes it a logical necessity to say that the defendant has attempted to commit a crime or that he has not. Experts appear to differ. In the stump case some would hold that there was no indictable attempt because shooting at a stump is not a crime, ${ }^{, 51}$ whereas in the rape case there is an attempt for the reason that the mere impossibility of success does not prevent this from being an indictable attempt.52 One author comes to the conclusion that if a man shoots at a hole thinking it is a policeman's eye he is not guilty, whereas if he shoots through a hole at a man who is not there he is guilty. ${ }^{53}$ This would be a curious basis upon which to determine whether a dangerous gunman should be freed.

Another line of reasoning holds that, as one of the "factual objectives" of the man who shoots at a stump is criminal he may therefore be guilty of an attempt; in the rape and forgery cases, however, none of the "factual objectives" being criminal the defendant may not be held.54 Even assuming the validity and pertinancy of the reasoning to this point, it seems to require further machinery. Accordingly it is suggested that the man who shot at a stump thinking it his enemy should be held only if his mistake was a reasonable one. Such a rule is open to two objections. Its justification is that society is in no danger from men who make unreasonable mistakes-a statement which would hardly appeal to the criminal psychiatrist. Furthermore, when we introduce the reasonable man test we have admitted that the rule cannot give us any more definite results than if we simply considered the policy of the statute. In short, we have merely evolved a cumbersome metaphysical machine which leaves us just where we started, without predictability.

50 State v. Snyder, 188 Iowa 1150, 177 N. W. 77 (1920), 10 A. L. R. 309 (1921), held not to be an attempt.

For an explanation of these cases on the theory that abortion statutes are passed only to protect the interest of the foetus and that no interest exists to be protected where there is no foetus, see Straham, op. cit. supra note 9 , at 979 .

51 Supra note 46.

52 Supra note 9.

53 Beale, op. cit. supra note 9 , at 495.

54 Sayre, op. cit. supra note 9, at 840, 852. 
Another author reconciles these cases by assuming a new abstraction, impossibility, and dividing it into three classes, (a) extrinsic impossibility, (b) intrinsic impossibility, (c) legal impossibility. ${ }^{55}$ Intrinsic and extrinsic impossibility both may or may not be a defense but legal impossibility will always be a defense. Again, the difficulties of defining impossibility without regard to what it is which is impossible may easily be imagined. The purpose of the classification, however, seems to be simply to justify convicting the defendant in case (1) above and acquitting him in cases (2) and (4).

The distinctions made by these authors are ingenious, but as they lead us either to absurd results or else to no results at all it is contended that they do no more than illustrate the fact that the search for general principles underlying the abstraction "intent" in criminal attempts is useless.

The second requisite of a criminal attempt may be stated as follows: The defendant must perform an act toward the accomplishment of the crime.

It appears to be customary to make two classifications here: (a) the means used must be reasonably adapted to the end; $: 0$ (b) the act must go beyond mere preparation.

Under the first heading we put cases where the defendant's acts were not interrupted but were inadequate to accomplish his purpose. Since a poorly aimed pistol cannot kill any more than a toy pistol, we encounter difficulties unless we wish to punish every impossible attempt. Therefore we invent phrases such as "reasonably adequate means." These are unobjectionable in so far as they are vague and in fact allow a degree of individualization; but they are objectionable when they induce the citation of all kinds of irrelevant cases under the theory that there is such a concept as reasonably adequate means applicable to attempts at all crimes. ${ }^{5 T}$ Occasionally this tendency leads to an absurd result, as in the cases where a defendant is discharged who has assaulted someone with a gun which the state could not prove was loaded, ${ }^{58}$ and in the cases, of which traces still remain, where a defendant attempting to pick an empty pocket is held not to have attempted a crime.0

55 Strahorn, op. cit. supra note 9.

56 WhARTON, op. cit. supra note 9, at $\$ \S 219,220$; Beale, op. cit. supra note 9, at 496 . Some of the theories and problems here have already been discussed under the heading of intent. The classifications are often confused.

${ }^{57}$ Cf. State v. Glover, 27 S. C. 602, 4 S. E. 564 (1888), and State v. Clarissa, $11 \mathrm{Ala} .57$ (1817), two cases difficult to reconcile under any general concept since the actual situations are very different.

ss See cases cited supra note 33 .

5 Regina v. Collins, 9 Cox C. C. 497 (1864), attempt to pick an empty pocket held not criminal; overruled in England by Regina v. Ring, 17 Co: 
Under the second heading we distinguish between "preparation" and attempt. Various tests have been laid down. ${ }^{\circ 0}$ The courts, while usually admitting that each case must be decided on its particular facts, continue to confuse their opinions by citing long lists of cases of quite different kinds of crimes. Here also, to discuss whether acts done in an attempted robbery are comparable to acts done in an attempted incestuous marriage, as they relate to the general principle of proximateness, is as valuable as discussing whether Milton is more poetical than a pig is fat. Yet this is constantly being done, again with occasional absurd results. The recent case of Peopla $v$. Rizzo ${ }^{\text {"1 }}$ furnishes a beautiful example. The four defendants in that case planned to rob a messenger carrying a payroll. Armed with guns they rode about looking for him. The police followed and arrested them as they ran into a building to commit the robbery. The payroll messenger was not in the building, and indeed the defendants never saw him. From an adverse decision in the trial court one of the defendants, Rizzo, appealed, but the New York Appellate Division affirmed the conviction. ${ }^{62}$ It seemed to that court that the case resembled an attempt to pick an empty pocket. The majority opinion, however, closed with the following paragraph:

"The trial of a criminal case should be a search for the truth, not a contest over technicalities. Here the defendant did everything in his power to successfully carry out the robbery. He failed only because of the alertness of the detectives who prevented its perpetration and saved the proposed victim." ${ }^{03}$

Two judges dissented on the ground that the conduct of the defendants constituted mere preparation under the principles laid down in the incestuous marriage case. A paragraph from that extraordinary case was cited. The Court of Appeals followed the dissenting judges. Their opinion is very interesting. It commences with a paragraph congratulating the police on their excellent work in preventing a serious crime. The body of the opinion then explains why the act of the defendant was

C. C. 491 , (1892) ; overruled in America by Commonwealth v. McDonald, 5 Cush. 365 (Mass. 1850), and other cases; revived again in Peoplo v. Purcell, 269 Ill. 467, 109 N. E. 1007 (1915), holding that there can be no attempt to steal from one who has nothing of value on his person, and carefully distinguishing the Massachusetts case where value was not involved. These pickpocket cases are discussed by Mr. Sayre under reasonable mistake of fact.

${ }^{60}$ (1924) 24 CoL. L. Rev. 790; (1928) 12 MrNN. L. Rev. 658; 8 R. C. L. 278.

21246 N. Y. 334,158 N. E. 888 (1927).

62 People v. Rizzo, 221 App. Div. 353, 223 N. Y. Supp. 200 (1st Dop't 1927).

${ }^{63}$ Ibid. 356, 223 N. Y. Supp. at 203. 
not one "done with intent to commit a crime and tending but failing to effect its commission." The concluding paragraph urges the governor to pardon the three defendants who did not appeal and were therefore in prison. It was not considered fair to permit them to remain incarcerated simply because they were not possessed of sufficient mental agility to realize their own innocence.

While the above account of the reasoning of the court makes it seem absurd to congratulate the police for arresting persons who had not committed the crime they were arrested for, ${ }^{\text {ca }}$ perhaps it is not a fair statement in as far as it does not take into consideration the logical difficulties before the court arising from the law of criminal attempts. If we assume, as the court did, the existence of rules governing attempts in general, we may well come to the conclusion that it is better to let these robbers go free than to run the risk of having to imprison other persons who did similar acts in the attempted commission of more trivial offenses. Criticism should be directed not against a great court which felt itself bound to follow an ancient course of reasoning, but rather against the utility of the abstractions of criminal attempts as substantive crimes. The reasoning of the opinion is as coherent as the nature of the abstractions permit and the case is a very useful one, though not perhaps for the purpose that the court intended it.

The final requisite of a criminal attempt is that it must have failed. ${ }^{65}$ Does this mean that if a defendant is indicted for an attempt and convicted it is prejudicial error if the evidence happened to show that he was successful? If so we have another abstraction to define, to-wit, "failure." co Does this re-

64 Curiously enough legal commentators saw nothing out of the way in the case. The writer of a note in (1928) 12 MINN. L. REv. 658 sees only a test of what is preparation. Mr. Strahorn considers it an excellent example of "extrinsic impossibility excusing the criminal attempt." There is of course no record of how the police or the pardoned gangsters felt about it, but this is assumed to be unimportant. If the public objects their recourse is with the legislature. Yet what more can the legislature say since the act already provides that "an act done with intent to commit a crime and tending but failing to effect its commission" is an attempt. N. Y. PExar LAW § 2.

65 Cases are collected in Sayre, op. cit. supra note 9 , at 838 ; 16 C. J. 113, n. 17; Wharton, op. cit. supra note 9 , at $\$ 212$. Contra: State v. Shepard, 7 Conn. 54 (1865). Mrany statutes allow a conviction for attempt under an indictment for the completed crime. People v. Vanderbilt, 199 Cal. 401, 249 Pac. 867 (1926).

66 An abstraction even as general as this one may be of great value so long as its purpose is kept in mind. If a court makes "failure" an element of attempt for purposes of instructing the jury but refuses to allow this conception to be used to reverse a case merely because the evidence showcd the defendant was successful, the conception of failure is very useful. However, when we make failure a fixed conceptual element of attempt for 
quirement also apply to every statute where the word attempt is used-e.g. one relating to confidence games-which may obviously be drawn to avoid just such technicalities? or It probably does if we are forced to classify all statutes which use the word "attempt" together, regardless of the thing they prohibit.

Two questions remain for discussion:

(1) Is there a simpler method by which the courts can talk about attempts at crimes?

(2) If a simpler method exists does the so-called weight of authority prevent the courts from adopting it?

May we not restate our generalizations so as to describe more accurately the results of the past and cause less confusion in the future? Suppose we say that the law of criminal attempts is not a classified, set of rules describing the elements of any crime or covering any given conduct. When we talk about the law of criminal attempts in general suppose we refer to it as a power or discretion that has been given to the courts either by the legislature or by common law precedent to extend the limits of prohibitions against certain kinds of conduct to conduct which does not quite fall within the terms of those prohibitions. We immediately recognize that this power is very

all purposes, we get results like this: The defendant was attempting to stenl from a store but when accosted left the premises. Later his overcoat was found on the showcase with merchandise in the pockets. He was indicted for larceny. The jury, quite reasonably, thought he had been unsuccessful and convicted him of attempt. The upper court argued: (a) Failure is an element of attempt; (b) a simple asportation is a successful larceny; (c) therefore the defendant was successful and his conviction is roversed. Bunn v. Butler, 300 Ill. 269, 133 N. E. 246 (1921).

67 A statute in Illinois penalized "every person who shall obtain, or attempt to obtain" money by means of a confidence game. This valiant attempt of the legislature to penalize fraudulent conduct was defeated by the Illinois Supreme Court in the following ingenious way: $(a)$ the use of the word "attempt" in the statute makes all the old common law decisions relevant; (b) consequently the statute defined two separate crimes, the completed crime, and the attempt; (c) the evidence showed success; (d) therefore a conviction for attempt must be reversed. Graham v. People, 181 Ill. 477,55 N. E. 179 (1899).

This case is then used to prove the result in the larceny case, supra noto 66.

Later a conviction for indecent liberties was appealed. The instruction, using the exact language of the statute, informed the jury that any person "who shall take or attempt to take" liberties, etc. is punishable. The Illinols Supreme Court held that the statute created two crimes with the samo penalty; that failure was an element of one but not of the other; that under the instruction given the jury might get these crimes mixed, which would interfere with the conception of failure as an element of criminal attempts. Therefore the conviction was reversed, acting on the strength of the case of Graham. v. People, supra, though the evidence showed a brutal assault. People v. Crane, 302 Ill. 217, 134 N. E. 99 (1922). 
similiar to the power which courts have given themselves in that vague field known as common law crimes. This is a most useful logical device and, while it may seem vague, no one considers it confused. ${ }^{68}$ For example, suppose that a careless legislature omits the penalty in a criminal statute. The device of common law crimes provides a way out of the dilemma. A sketchy criminal code omits to prohibit an obviously dangerous kind of conduct. The power to punish for common law crimes gives the court freedom to act without appearing to encroach upon the legislature. We are content to define this power in terms which are broad enough to cover any case which might arise. The vagueness of our definition, however, does not bother us because we do not regard the law against common law crimes as a law which must be enforced, such as the prohibition law or the law against murder. Instead, we regard it as a useful device under which courts are free to fill up omissions in criminal codes.

The law of criminal attempts is exactly the same kind of a thing. Considered apart from any particular crime it simply means that courts are permitted to fill in the gaps which a set of definitions inevitably leave when applied to human conduct. The power to interpret statutes performs a similar function, but the rules of statutory interpretation of criminal statutes are never considered as definitions of crimes. The power to punish for criminal attempts gives the court power to extend a criminal statute without distorting its language. It is necessary to our criminal system. To treat this power as the definition of a substantive crime is either to destroy it or hopelessly to confuse it.

Certainly confidence game statutes, pandering statutes, prohibition laws, speed laws, laws against robbing the United States mail, sedition laws, etc., were all passed to meet entirely different problems. The court is given the power to extend the policy of these statutes to conduct not included within their specific language. Some of them will be extended to cover attempts, others will not. Very often, an emotional reaction toward the kind of conduct prohibited by the statute is about all that will guide us. Thus we probably will not punish an attempt to drive while intoxicated, but we will punish an attempt at statutory rape. We will not punish attempts at attempts for the purely administrative reason that it is cumbersome procedure-but we may depart from this rule if a feeling of fairness compels us to adjust the penalty. Can we determine in

${ }^{68}$ By vagueness we mean simply a lack of predicability; by confusion we mean the existence of elaborate machinery, which cannot be described, which operates on dissimilar situations, and which has a tendency to produce irrational results. 
advance how we are going to feel about any one of these thousands of crimes, now existing or about to be created, by formulating rules which apply equally to all attempts at the conduct prohibited by all of them? Is it useful to pretend that we can?

We may therefore restate the Law of Criminal Attempts as follows :

The Law of Criminal Attempts and the Statutes making attempts generally punishable give the courts a power to extend the policy ${ }^{69}$ or limits of any particular criminal prohibition to cover (a) conduct which is not within the definition laid down by that rule but which in its tendencies is within its policy; or (b) conduct which is not sufficiently serious to make a court willing to apply the penalty provided in the particular rule invoked, but which it nevertheless feels should not go unpunished. We cannot go further than this without having the particular rule invoked before us.

Certain other propositions, mostly negative, follow from this statement.

1. A criminal attempt is not a substantive crime without reference to the thing attempted, and the concept of it as such is not a workable legal device.

2. Whether the power to punish for criminal attempts will be applied to any particular crime will depend on the attitude of the court toward the advisability of extending the rule prohibiting that particular crime.

3. The closely related questions as to whether the defendant's conduct was sufficiently blameworthy to deserve to be punished under the particular rule invoked (here we have the whole problem of "intent") or whether his conduct was sufficiently dangerous (here we have the problem of whether the means were adapted to the end, reasonable mistake in the menns chosen, etc.,) or whether it was sufficiently far advanced toward its objective (here we have the question as to when "mere preparation" becomes an attempt) have no meaning or content when considered apart from the particular prohibition.

4. Solicitation involves the same considerations as attempts. The conduct simply consists of hiring or inducing someone to act instead of acting oneself. Courts should assume the same kind of power to extend the limits of a given rule to cover persuasion and inducements, as well as conduct, where the policy of the particular rule seems to require it. There is no object in treating it differently from attempt. The distinction between solicitation and attempt leads to an occasional absurd result, but

69 The word "policy" is selected because it does not pretend to havo a definite meaning. If we take a word which pretends to have definablo elements, sve make all cases or statutes using that word relovant. Howovor different they are the use of the word binds them together. 
usually it is a harmless device for relieving a defendant of liability under an attempt indictment when his conduct seems not sufficiently serious to merit court action. The question of the determination of the crimes, solicitation to which is criminal, is one that cannot be limited by set rules apart from the consideration of the particular crime solicited.:0

The description of the law of criminal attempts as a power eliminates the artificial definition of criminal intent in all attempt cases and the doubt and worry as to whether a person in the abstract can blunder into an attempt in the abstract. It also relieves us from difficulty in the cases which are always so hard to reconcile. For example, an attempt at rape by a boy under fourteen is not punishable as attempted rape because the same policy which prevents small boys from being punished for the principal crime applies to the attempted crime. That this policy is not based on artificial conceptions of the nature of impossibility is evident from the decisions. Most boys under fourteen are incapable of rape and if one does exist he is suffciently abnormal to deserve a different kind of treatment. There is nothing in this common sense result which need confuse us in a case where the defendant tries to shoot a man who does not happen to be where the defendant thinks he is. We need have no further difficulty with the case which holds that raising the figures on a check is not an attempt at forgery. Obviously, forgery is the kind of crime which is often not prosecuted if the loss is made good and we do not have the same desire to extend its limits as we do in the case of murder. The same is true of the case where the defendant was indicted for attempt to contract an incestuous marriage. The court undoubtedly felt that nothing short of the completed crime should be punished. It placed the acts of the defendant under the category of preparation only because it did not feel free to state the reasons for its opinion. Whether the attempt to administer poison which is not noxious enough to cause death is an attempt at poisoning certainly must depend upon the court's attitude toward murder, and not on the doctrine that we will punish only those who act reasonably because unreasonable persons are not dangerous. Abortion presents a problem as different from poisoning as can be imagined. If Lady Eldon was guilty of an attempt to smuggle when she had only non-dutiable goods, ${ }^{71}$ and $\mathrm{Mr}$. Jaffe was not guilty of an attempt to receive stolen property when the goods had been repossessed by the

70 Thus the making of incendiary speeches and the publication of antisocial doctrine are more logically classified under the power to punish common law crimes than under solicitation or attempt.

i1 See supra note 48. 
owner, ${ }^{72}$ we may find the explanation very easily in the different attitude of courts toward larceny and smuggling. Larceny has always been the playground of the law. If the Jaffe case reaches an absurd result it is because the elaborate machinery which the court used made it possible by concealing the real issue of legislative policy behind a formula which describes all attempts in general terms. The painful struggle which courts had and still have with cases involving picking an empty pocket would have been avoided if they had not been trying to define attempt without relation to the thing attempted.

Does the so-called weight of authority compel the court to talk in these concepts, or may they be permitted to talk about the particular issue they are considering without either creating uncertainty in the criminal law or committing the crime of judicial legislation.

An examination of the cases indicates not only that courts are free to throw all this machinery overboard, but that they are actually doing it in most cases. The great body of this attempt philosophy comes from the interpretation of statutes defining certain special conduct as criminal. There is no conceivable reason in the rule of stare decisis why, the courts in interpreting these statutes should not talk about the particular conduct prohibited. Moreover, there is no reason why a decision interpreting one statute should bind the court in the case of an entirely different statute merely because both are part of the Criminal Code.

A second class of cases involving these attempt formulae comes under statutes punishing general attempts; these are said to embody the common law though they often change the penalty. That such statutes are designed to catch omissions in not providing more particular statutes is obvious. While their general form may lead us into undue generalization nevertheless an examination of the cases shows that courts are omitting to talk in the formula of attempts without relation to the thing attempted. It is significant to note that in the year 1930 the Century Digest found only five cases which, on account of the headnote or language of the opinion, it considered should be classified under attempt, as a criminal law topic. It is significant too that in Mr. Sayre's very exhaustive article setting out the logical approach to the law of criminal attempt, out of the 83 cases cited on which his generalizations are based, 71 were decided before 1910 , only 4 after 1915 , and the very latest case in 1919. It is also interesting to note that out of all these cases only about one fourth deal with attempts in general, either under the common law or so-called general attempt statutes. The other three-fourths are interpretations of statutes

72 People v. Jaffe, 185 N. Y. 497, 78 N. E. 189 (1906). 
dealing with particular classes of conduct such as assaults with intent to kill, and the like.

Nor does the distinction between solicitation and attempt rest on any such body of respectable authority that courts are compelled to continue it if they prefer a more realistic treatment. Most of the cases noting this distinction are cases where the act of solicitation is not serious enough to be punishable, whether considered as a separate crime or not. These may be called the "mere solicitation" cases. The occasional decision, by which a defendant deserving punishment is freed because he is indicted for solicitation when he should have been indicted for attempt, is becoming more and more difficult for our courts to make. Crime commissions and other critics have fallen into the habit of enumerating reversals on technicalities and writing about them critically. ${ }^{73}$ Such decisions no longer appear to be as inevitably compelled by inexorable logic as they once were.

\section{CONCLUSION}

In criminal law as elsewhere, concepts and abstractions are necessary to the administration of justice. It is the primary business of appellate courts to create them and to keep them up to date by changing their content and scope as may be necessary to adjust them to each new case. It follows that some of these concepts develop with a certain degree of symmetry and usefulness. Others do not. Of those that fail in their purpose, some produce results which offend persons of influence to such an extent that they are changed by the legislature. But not all useless rules and concepts succeed in offending people of sufficient importance to get themselves repealed. They may, as in the case of criminal attempts, be too confused to be susceptible of repeal. Enough books may have been written about them, enough vested interests acquired in their verbal structure, so that they may be strong enough to repeal the very statutes which seek to change them. This too has sometimes happened in the case of criminal attempts. Of course such concepts must not be too outrageous if they are to survive. The old common law distinction between larceny and embezzlement became too unmanageable to continue. But the law of criminal attempts has exercised more moderation; its very vagueness has been its salvation, for it makes it possible to arrive at good results in many cases. It is only in the occasional case that it achieves an absurdity. Nevertheless it remains with us, a complete obstacle to intelligible judicial speech and an encumbrance on intelligent judicial action.

It is too seldom recognized by legal theorists that courts have

${ }^{3}$ For example see Harno, The Supreme Court in Felony Cases, ILr. CrIME SURVEY (1929) 113, 219. 
a duty to get rid of useless abstractions and to reclassify the situations which come before them for judgment, that this duty may at times be more important than the further refinement and analysis of ancient rules. Of course it must be recognized that there are interesting psychological hazards involved in eliminating an old abstraction which do not stand in the way of creating a new one. The court often does not feel quite sure but that the abstraction may, not be of use in some case which is not before it at the time. It does not ordinarily have the opportunity of investigating how much law it is repealing and the notion of the law as a seamless web makes it hesitate. There is a feeling that an attack on a particular abstraction makes the world less safe for all abstraction. These considerations, however, do not excuse legal writers; yet there is astonishingly little research done for the purpose of getting rid of useless logical machinery. Most writers on confused legal situations seek to qualify and analyze the useless abstractions until they obtain at least an appearance of certainty. They do not like to admit frankly that some situations where predictability is impossible can be handled more intelligently with less logical machinery, rather than with more, because the presence of an elaborate set of principles adds an additional and unnecessary element of uncertainty by diverting the court's mind fr'om the real question to the rules.

Unintelligible judicial opinions and an occasional absurd result have, moreover, a peculiarly unfortunate result in the driminal law. It is true that faulty court procedure does not have the effect on the problem of crime which is often supposed. Nevertheless it is of the utmost importance that the man on the street should feel that criminal justice is being administered fairly, non technically and intelligently. He has the ability to judge the results and reasoning of a criminal case better than a civil case because the situation is within his comprehension and he is more interested. His attitude toward courts in general is determined largely by their efficiency in criminal cases. Dean Pound has said that the extraordinary lack of power allowed to American judges may well be due to the impressions of the ruthless administration of criminal law by Jeffries which our early settlers carried from England. Most aspects of the problem of dealing with crime are necessarily for the legislature. But it is not too much to expect that courts will, without legislative assistance, at least free themselves, from useless abstractions too complicated for the legislature to understand. In this direction the help of the legal theorist is much needed, whether or not his conclusions add to the dream of predictability in the administration of the criminal law. 